Tobace/mokin/ Heatth. JNSF23-3-91

613.84

J. Natn. Sci. Coun. Sri Lanka 1995 23(3): 91-96

\title{
BIOCHEMICAL CHANGES IN BEEDI SMOKERS
}

\author{
VASANTHY ARASARATINAM, ${ }^{*}$ K. BALASUBRAMANIAM, S. RAJENDRA \\ and S. RAGAVAN \\ Department of Biochemistry, Faculty of Medicine, University of Jaffna, Kokuvit.
}

(Received: 03 June 1994; accepted: 07 July 1995)

\begin{abstract}
Beedi smoking is common in Sri Lanka and hence a study was undertaken to determine the effects of beedi smoking on selected clinical biochemistry parameters. Thirty non-alcoholic beedi smokers and thirty nonalcoholic non-smokers from the same socio-economic status were selected from the Jaffna Municipality. The mean ages of beedi smokers and non-smokers were $45( \pm 6.4)$ and $44( \pm 7.3)$ y respectively. Mean serum ascorbic acid and protein levels were significantly decreased in beedi smokers. Although plasma fibrinogen level in beedi smokers was within normal range, it was significantly elevated compared to non-smokers. Beedi smokers showed a significant elevation in serum bilirubin level. Serum alanine transaminase (AUT) in beedi smokers was significantly elevated while aspartate transaminase (AST) showed no significant change. Glucose tolerance was significantly decreased in smokers. Furthermore urinary excretion of creatine was significantly increased while the urine volume and creatinine excretion were not significantly altered in beedi smokers.
\end{abstract}

Keywords: Beedi smokers.

\section{INTRODUCTION}

Tobacco smoke increases morbidity and mortality in smokers and non-smokers..$^{1,2}$ According to a survey carried out in 1989 in Sri Lanka, 33.4\% were current smokers, $4.4 \%$ were ex-smokers and $62.2 \%$ were non-smokers. ${ }^{3}$ Cigarette is most popular among the smokers and beedi is the second most popular product with $50.2 \%$ of the smokers smoking beedi alone or in combination with cigarette, pipe, cigar, etc. ${ }^{3}$ Cigarettes are not freely available in the North and East and at present therefore beedi is smoked instead. Studies on cigarette smokers reveal that smoking alters blood pressure, ${ }^{4}$ gastric function, ${ }^{5}$ serum cholestercl ${ }^{6}$ and plasma fibrinogen ${ }^{7}$ levels. This paper describes a study carried out to determine the effect of beedi smoking on selected readily - measured clinical biochemistry parameters viz. serum ascorbic acid, total protein and bilirubin levels, serum aspartate transaminase and alanine transaminase activities, plasma fibrinogen level, $\backslash$ glucose tolerance, urine volume and urinary excretion of creatine and creatinine. Significant alterations in these parameters may give information on the effects of beedi smoke ${ }^{8}$ on the metabolism ${ }^{9}$ of the smokers.

\section{METHODS AND MATERIALS}

Subjects: Thirty of each group of beedi smokers and non-smokers of the age group of 30-50 y were selected from the same socio-economic level. They were employed as drivers, cleaners and conductors. The non-smokers had never smoked cigárettes, beedi etc.. The selected subjects were all males and the number of

\footnotetext{
* Corresponding author.
} 
beedies smoked ranged from 10 to 25 (14.4 \pm 9.96$)$ per day. The mean period of smoking was 18.6 ( \pm 11.43$)$ y. The subjects were living in the same housing scheme and were settled after the displacement from their native places. Their monthly income ranged from Rs. 3000 to 4000 .

Biochemical analysis: Serum was analysed by standard procedures for ascorbic acid ${ }^{8}$ total protein, ${ }^{9}$ bilirubin ${ }^{8}$ and the activities of AST, ${ }^{10}$ and ALT. ${ }^{10}$ Serum ascorbic acid level was measured by 2,6-dichlorophenol indophenol method and it was performed immediately after withdrawing the blood (within 5 to $10 \mathrm{~min}$ ). Plasma fibrinogen ${ }^{8}$ was precipitated using calcium chloride ${ }^{8}$ and the protein estimated by Lowry's method. ${ }^{9}$ Modified glucose tolerance test was performed ${ }^{8}$ by collecting the blood and urine samples at $0 \mathrm{~h}$ and $2 \mathrm{~h}$ after the administration of glucose. The urine volume was measured and urinary creatine ${ }^{8}$ and creatinine ${ }^{8}$ levels were estimated by standard procedures. The alterations in the parameters were statistically analysed by the Student's $t$ test.

\section{RESULTS AND DISCUSSION}

Serum ascorbic acid level in the smokers was significantly decreased $(p<0.05)$ (Table 1). As the subjects were advised to take similar diet at least for one week before the commencement of measurements, the decrease in serum ascorbic acid level in the smokers could be due to high utilization of ascorbic acid in these individuals. This could be due to increased sympathetic activity caused by nicotine, which would increase the discharge of adrenalin from adrenal medulla. ${ }^{4}$ Furthermore acetaldehyde in beedi smoke may also increase the oxidation of ascorbic acid. Smoking is also associated with fibrous intimal thickening of arterioles. ${ }^{11}$ Ascorbic acid is needed as coenzyme in the hydroxylation reactions for the synthesis of adrenalin and in the post translational modification of procollagen.

Serum protein levels of beedi smokers were significantly reduced compared with non-smokers $(\mathrm{p}<0.05)$ (Table 1 ). This could be due to the disturbance in the metabolism of the amino acid pool in liver which may be a consequence of nicotine poisoning of vitamin $B_{6}$ (pyridoxyl phosphate). ${ }^{12}$ Smoking affects the sympathetic activity and leads to increased peristalitic movement. ${ }^{5}$ Increased peristalitic movement would lead to a decrease in protein digestion and malabsorption of digested products. The reduction in plasma protein level in beedi smokers can also be due to their poor dietary habits, malnutrition and nicotine-induced secretion of corticosteroids. ${ }^{6}$ Corticosteriods increase catabolism of protein.

Mean plasma fibrinogen level in non-smokers and beedi smokers were 0.21 $( \pm 0.02) \mathrm{gdl}^{-1}$ and $0.26( \pm 0.02) \mathrm{gdl}^{-1}$ respectively (Table 1$)$. The normal fibrinogen level ${ }^{12}$ in plasma is $0.2-0.3 \mathrm{gdl}^{-1}$. Though the plasma fibrinogen level in beedi smokers is within the normal range, their mean value is significantly elevated $(p<0.05)$ compared with non-smokers. Significant elevation in plasma fibrinogen level was reported for cigarette smokers. ${ }^{7}$ A strong positive correlation was noted between plasma fibrinogen and serum thiocyanate levels of smokers indicating that plasma fibrinogen level increases with an increase in exposure 
to cigarette smoke. ${ }^{7} \alpha-1$-Antiproteinase (formally called alpha-1 antitrypsin or a1-AT) is an enzyme synthesized by the liver that inhibits trypsin, elastase and certain other proteases by complexing with them. A particular methionine residue of a1-AT is involved in binding to proteases. Beedi smoking oxidizes the methionine residue to methionine sulfoxide and thereby inactivates a1-AT. This leads to the destruction of tissues and consequent increased fibrinogen. ${ }^{13}$ Adrenalin and noradrenalin released in response to increased sympathetic activity, bring about lipolysis in adipose tissue and the subsequent release of free fatty acid into plasma. ${ }^{4,12}$ In tissue culture it has been shown that free fatty acid increases the fibrinogen synthesis in human liver slices.

Table 1: Serum ascorbic acid, total protein and bilirubin levels, serum ALT and AST activities and plasma fibrinogen level in beedi smokers and non-smokers.

\begin{tabular}{|c|c|c|c|}
\hline Parameters & Non-smokers & Smokers & "t" test \\
\hline \multirow{2}{*}{$\begin{array}{l}\text { Serum } \\
\qquad \begin{array}{l}\text { Ascorbic acid } \\
\left(\mathrm{mg} \mathrm{dl}^{-1}\right)\end{array}\end{array}$} & & & \\
\hline & $0.88( \pm 0.15)$ & $0.40( \pm 0.24)$ & $\mathrm{p}<0.05$ \\
\hline $\begin{array}{l}\text { Total Protein } \\
\qquad\left(\mathrm{g} \mathrm{dl}^{-1}\right)\end{array}$ & $7.03( \pm 1.32)$ & $4.38( \pm 1.51)$ & $\mathrm{p}<0.05$ \\
\hline $\begin{array}{l}\text { Bilirubin } \\
\qquad\left(\mathrm{mg} \mathrm{dl}^{-1}\right)\end{array}$ & $1.14( \pm 0.08)$ & $2.03( \pm 0.06)$ & $p<0.05$ \\
\hline $\begin{array}{l}\mathrm{ALT} \\
\qquad\left(\mathrm{IU} \mathrm{I}^{-1}\right)\end{array}$ & $3.5( \pm 1.41)$ & $11.9( \pm 5.02)$ & $p<0.05$ \\
\hline $\begin{array}{l}\text { AST } \\
\qquad\left(\mathrm{IU} \mathrm{l}^{-1}\right)\end{array}$ & $13.0( \pm 4.24)$ & $14.4( \pm 4.27)$ & n.s. \\
\hline $\begin{array}{l}\text { Plasma fibrinogen } \\
\qquad\left(\mathrm{mg} \mathrm{dl}^{-1}\right)\end{array}$ & $0.21( \pm 0.02)$ & $0.26( \pm 0.02)$ & $\mathrm{p}<0.05$ \\
\hline
\end{tabular}

p - probability; n.s. - not significant

The serum bilirubin level was significantly higher in beedi smokers than non-smokers $(\mathrm{p}<0.05)$ (Table 1$)$. Normally little oxidation of haemoglobin to methaemoglobin takes place during the oxygenation of haemoglobin and this oxidation is catalysed by superoxide anion which is normally converted to water with the help of NADPH. ${ }^{12}$ Several constituents of cigarette smoke, including nicotine, stimulate the activity of hepatic cytochrome $\mathrm{P}_{450}{ }^{14}$ where NADPH is utilized. ${ }^{12}$ The composition of cigarette smoke is complex and it contains many compounds that are likely to induce the monooxygenase activity. ${ }^{14}$ Further smoking alters oestrogen metabolism, which is responsible for induced activity 
of hepatic monooxygenase with subsequent effects on steroid hormone and porphyrin metabolism. Such effects of cigarette smoke can also be caused by beedi smoke as the constituents of beedi and cigarette smokes are relatively similar. ${ }^{15}$ Further the carbon monoxide in beedi smoke may react with haemoglobin and lead to the formation of carboxy haemoglobin. Therefore increase in methaemoglobin and carboxy haemoglobin would lead to increase in haemolysis. Increased haemolysis may be responsible for the increase in serum bilirubin levels in smokers.

The ALT levels ${ }^{10}$ in reference subjects fall between 4-20 $\mathrm{IUl}^{-1}$. Although the difference between the smokers and non-smokers was statistically significant $(\mathrm{p}<0.05)$ (Table 1), the ALT level in beedi smokers was in the upper limit of the normal range. It could be suggested that the subjects have not yet been exposed sufficiently to produce extensive tissue damage such as in the liver.

The difference in the AST levels in both groups was statistically not significant $(p>0.05)$ (Table 1). However it has been suggested that severe smoking may lead to cardio-vascular diseases with significant elevation in AST level..$^{16,17}$

The ability of the body to utilize glucose may be ascertained by measuring the glucose tolerance. A modified glucose tolerance test was carried out where the blood glucose level was monitored at $0 \mathrm{~h}$ and $2 \mathrm{~h}$ after the glucose load (Table 2). A significant reduction in blood glucose level after the glucose load and thus a good glucose tolerance was observed in non-smokers. However a significant elevation in blood glucose level after the glucose load was observed in beedi smokers $(\mathrm{p}<0.05)$ (Table 2). Thus decreased glucose tolerance was seen in beedi smokers. The nicotine induced sympathetic activity and the release of adrenalin ${ }^{14}$ inhibit the release of insulin from beta-cells of pancreas which is mediated via $\alpha$-receptors. In beedi smokers the increase in plasma insulin after a glucose load may therefore be lower than in non-smokers, which explains the observed decrease in glucose tolerance in smokers. Slightly elevated fasting glucose level in beedi smokers may be due to glycogenolysis and gluconeogenesis under the influence of catecholamines. ${ }^{12}$.

Table 2: Results of modified glucose tolerance test performed in beedi smokers and non-smokers.

\begin{tabular}{llrl}
\hline & \multicolumn{2}{c}{$\begin{array}{c}\text { Blood glucose } \\
\left(\mathrm{mg} \mathrm{dl}^{-1}\right)\end{array}$} & \\
\cline { 2 - 3 } Time & Non-smokers & Smokers & "t" test \\
\hline $0.0 \mathrm{~h}$ & $82.42( \pm 13.23)$ & $94.50( \pm 17.12)$ & $\mathrm{p}<0.05$ \\
$2.0 \mathrm{~h}$ & $80.46( \pm 14.72)$ & $109.48( \pm 23.02)$ & $\mathrm{p}<0.05$ \\
\hline
\end{tabular}

p - probability 
The urinary excretion of creatine was significantly increased in beedi smokers $(p<0.05)$ while the creatinine excretion was not significantly elevated $(p>0.05)$ (Table 3). This can be attributed to the a1-AT inactivation mechanism mentioned above. Dietory effect cannot be considered as responsible for the differences between smokers and non-smokers as the subjects had similar food habits. Catabolism of muscle proteins could have been the cause for increased creatine excretion in beedi smokers. There was no significant reduction in the urine volume of beedi smokers ( $p>0.05$ ) (Table 3). Slight reduction in urine volume could be due to nicotine induced secretion of $\mathrm{ADH}$ from posterior pituitory. ${ }^{18}$

Table 3: Urine volume and urinary excretion of creatine and creatinine by beedi smokers and non-smokers.

\begin{tabular}{lccc}
\hline Parameters & Non-smokers & Smokers & "t" test \\
\hline Urine volume & $1350.00( \pm 158.10)$ & $1300.00( \pm 124.1)$ & n.s. \\
$\begin{array}{l}\text { Creatine } \\
(m \text { mole })\end{array}$ & $0.13( \pm 0.05)$ & $0.31( \pm 0.13)$ & $\mathrm{p}<0.05$ \\
$\begin{array}{l}\text { Creatinine } \\
(\mathrm{m} \text { mole })\end{array}$ & $12.00( \pm 1.32)$ & $12.50( \pm 0.91)$ & $\mathrm{n} . \mathrm{s}$. \\
\hline
\end{tabular}

p- probability; n.s. - not significant.

\section{Acknowledgement}

We thank the subjects for their cooperation, V. Balasingam for technical assistance and the University of Jaffna for research support.

\section{References}

1. Goonaratnam C. (1991). Tobacco companies to be allowed to increase the numbers of our citizens maimed and killed by smoking. Ceylon Medical Journal 36(13):

2. Chambers J., Killoran A., Mc Neil A. \& Reid D. (1991). The health of nations: responses: smoking. British Medical Journal 303(6808): 973-977.

3. National Cancer Control Program, Sri Lanka (1989). Smoking pattern in Sri Lanka

4. St. George I.M., Williams S., Stanton W.R. \& Silva P.A. (1991). Smoking and blood pressure in 15 year olds in Dunedin, New Zealand. British Medical Journal 302(6768): 89-90. 
5. Johnson R.D., Horowitz M., Maddow A.F., Wishart J.M. \& Shearman D.J.C. (1991). Cigarette smoking and rate of gastric emptying effect on alcohol absorption. British Medical Journal 302(6767): 20-23.

6. Ramsdale D.R., Farágher C.B., Bray C.L., Bennett D.H., Ward C. \& Benton D.C. (1985). Smoking and coronary artery disease assessed by routine coronary arterigraphy. British Medical Journal 290: 197-200.

7. Athukorala T.M.S. \& Pushpa Rajini L.P. (1991). Lipid pattern and fibrinogen levels of smokers and non-smokers. Ceylon Medical Journal 36(13): 98-101.

8. Varley H., Gavenlock A.H. \& Bell M. (1980). Practical clinical biochemistry. Vol. 1. 5th ed. William Heinemann Medical Books Ltd, London.

9. Lowry D:H., Rosenbrough M.H., Farr A.L. \& Randall R.J. (1951). Protein measurement with Folin - Phenol reagent. Journal of Biological Chemistry 193: $265-275$.

10. Wooton J.D.P. (1964). Micro analysis in medical biochemistry. 4th ed. J \& A Churchill Ltd, London.

11. Chander W.U. (1986). Banishing tobacco. World Health. June, 4-5.

12. Murray R.K., Granner D.K., Mayes P.A. \& Rodwell V.W. (1993). Harper's biochemistry. 23rd ed. Prentice - Hall International Inc., U.S.A.

13. Ernest E.(1992). Fibrinogen. British Medical Journal 303(6803): 596-597.

14. Lip G.Y.H., Mc Call K.E.L., Goldberg A. \& Moore M.R. (1991). Smoking and recurrent attacks of acute intermittent porphyria. British Medical Journal 302(6775): 507.

15. Smoking; world trends and their implications (1987). Bulletin of the World Health Organization 65(3): 409.

16. Aureback O., Hammand E.C. \& Garfinkel L. (1965). Smoking in relation to atherosclerosis of the coronary arteries. New England Journal of Medicine 273: 775-779.

17. Banita R., Scragg R., Stewart A., Jackson R. \& Beaglohole R. (1986). Cigarette smoking and risk of premature stroke in men and women. British Medical Journal 293:6-8.

18. Ganong W.F. (1993). Review of medical physiology. 16th ed. Prentice - Hall International Inc., U.S.A. 